\title{
Kombinasi Fitur Tekstur Local Binary Pattern yang Invariant Terhadap Rotasi dengan Fitur Warna Berbasis Ruang Warna HSV untuk Temu Kembali Citra Kain Tradisional
}

\author{
Muhamad Nasir ${ }^{1}$, Nanik Suciati ${ }^{2}$, Arya Yudhi Wijaya ${ }^{3}$ \\ 1) Jurusan Teknik Informatika, Politeknik Negeri Bengkalis, Bengkalis \\ ${ }^{2,3)}$ Jurusan Teknik Informatika, Fakultas Teknologi Informasi \\ Institut Teknologi Sepuluh Nopember, Surabaya \\ e-mail: biruhitam.nasir@gmail.com ${ }^{1)}$,nanik@if.its.ac.id ${ }^{2}$, arya@ cs.its.ac.id ${ }^{3)}$
}

\begin{abstract}
ABSTRAK
Salah satu bagian penting dari sistem temu kembali adalah metode ekstraksi ciri. Metode ekstraksi ciri harus invariant terhadap perubahan rotasi, hal ini dikarenakan user sering mamasukkan citra contoh yang berbeda rotasi dengan citra yang ada di database. Pada kasus temu kembali citra kain tradisional, tekstur dan warna merupakan fitur dominan serta karakteristik visual yang penting dalam membedakan antara kain yang satu dengan kain yang lain. Oleh karena itu, pada penelitian ini dikombinasikan fitur tekstur Local Binary Pattern (LBP) yang invariant terhadap rotasi dengan fitur warna dari ruang warna HSV untuk temu kembali citra kain tradisional. Hasil kombinasi fitur tekstur LBP yang invariant terhadap rotasi dengan fitur warna dari ruang warna HSV menghasilkan recall terbaik $100 \%$ pada dataset Batik dan 100\% pada dataset Songket menggunakan jarak manhattan.
\end{abstract}

Kata Kunci: Kain Tradisional, Temu Kembali, Local Binary Pattern, Ruang Warna HSV, Perhitungan Jarak.

\begin{abstract}
One important part of the retrieval system is a feature extraction method. Feature extraction methods should invariant to changes in the rotation, because users often enter different sample image rotation of the image in the database. In the case of image retrieval traditional cloth, textures and colors are dominant features and visual characteristics that are important in distinguishing between the cloth with each other cloth. Therefore, in this study combined texture features Local Binary Pattern (LBP) which is invariant to rotation of the color features of the HSV color space for image retrieval traditional cloth. The result of features texture combination of invariant local binary pattern to rotation with color feature based HSV color space produces the best recall of $100 \%$ on a dataset Batik and $100 \%$ on a dataset Songket using manhattan distance.
\end{abstract}

Keywords: Traditional Cloth, Retrieval, Local Binary Pattern, HSV color space, Distance Calculation

\section{Pendahuluan}

Indonesia adalah salah satu negara yang kaya akan motif-motif kain tradisional. Hampir di setiap daerah mempunyai budaya yang tercermin dalam jenis kain khasnya masing-masing yang disebut kain nusantara. Dari cara pembuatannya, kain nusantara pada umumnya dikenal dengan cara membatik dan dengan alat tenun. Pembuatan satu lembar kain baik dengan cara membatik maupun menenun membutuhkan proses yang cukup rumit dan waktu yang sangat panjang tergantung dari tingkat kerumitan desain motifnya. Dari jenisnya, pada umumnya dikenal tiga macam kain nusantara, yaitu Batik, Tenun, 
dan Songket yang masing masing mempunyai keunikan dan tingkat kesulitan tersendiri dalam proses pembuatannya (Malik. 2004). Dokumentasi terhadap kekayaan kain khas Indonesia sangat diperlukan. Untuk membantu proses pendokumentasian citra kain tradisional, dibutuhkan sistem temu kembali yang cukup handal dalam menemukan dan mengidentifikasi citra kain tradisional. Salah satu bagian penting dari sistem temu kembali adalah metode ekstraksi ciri. Tekstur dan warna merupakan fitur dominan serta karakteristik visual yang penting pada kain tradisional dalam membedakan antara kain yang satu dengan kain yang lain. Untuk mendapatkan hasil ekstraksi ciri yang baik, diperlukan metode yang bisa merepresentasikan ciri tekstur dan warna pada kain tradisonal dengan handal.

Beberapa penelitian telah dilakukan untuk mengekstraksi ciri motif dasar pada beberapa kain tradisional, baik untuk sistem temu kembali citra maupun untuk sistem klasifikasi citra kain. Salah satu metode ekstraksi ciri tekstur yang handal adalah Local Binary Pattern (LBP) (Ojala et al. 1996). LBP adalah metode yang cukup sederhana, namun effisien dalam merepresentasikan ciri tekstur. Operator LBP hanya terdiri dari beberapa piksel tetangga dengan operasi perhitungan yang tidak rumit. Selain itu, LBP merupakan metode yang gray-scale invariant, atau tidak terpengaruh pada pencahayaan yang tidak merata pada citra, karena LBP mendeskripsikan tekstur secara lokal. Kinerja LBP dibandingkan dengan beberapa metode ekstraksi ciri tekstur yang lain, seperti Gray-level difference method, Law's texture measures, dan Center-symmetric covariance measures. Dari penelitian tersebut menunjukkan bahwa LBP dapat mencapai nilai rata-rata error paling rendah dibandingkan metode ekstraksi ciri tekstur yang lain, yaitu 2,3\% pada citra berukuran $32 \times 32$, dan $12,5 \%$ pada citra berukuran 16x16. LBP memiliki beberapa macam variasi yakni LBP yang invariant terhadap rotasi atau LBPROT diusulkan oleh ( Pietikäinen et al. 2000) untuk memperbaiki kinerja dari LBP yang diaplikasikan pada dataset Brodatz. Hasil penelitian sudah berhasil dengan nilai ratarata error LBPROT pada data Brodatz yaitu $39,2 \%$ pada citra $64 \times 64$ dan $47,7 \%$ pada citra $32 \times 32$. Namun pada metode ini terdapat kelemahan yaitu ada karakteristik lokal dari citra yang diabaikan sepeti kekontrasan. Terdapat juga penelitian (Ojala. 2002) mengusulkan Multiresolution Gray-Scale and Rotation Invariant Texture Classification with Local Binary Patterns yang digunakan pada dataset Outex dan dataset Brodatz. Hasil dari penelitian ini menunjukkan bahwa penelitian yang diusulkan dapat meningkatkan nilai rata-rata akurasi yang lebih baik dibandingkan dengan LBPROT. Sembilan pola uniform berkontribusi ratarata hampir $90 \%$ dari total data pola. Penelitian selanjutnya melakukan klasifikasi tekstur yang diaplikasikan pada dataset Brodatz (Doost \& Amirani 2013). Hasil penelitian menunjukkan kinerja yang sangat baik dalam klasifikasi tekstur dan robust terhadap rotasi yang berbeda-beda, metode ini juga memiliki komputasi yang sederhana. (Gao et al. 2011) melakukan kombinasi fitur tekstur dan warna untuk temu kembali citra untuk database Corel. Hasil penelitian menunjukkan kombinasi dua fitur memiliki kinerja lebih baik daripada hanya menggunakan fitur tunggal.

Model warna HSV merupakan model warna yang mendefinisikan warna berdasarkan terminologi Hue, Saturation dan Value. Hue digunakan untuk membedakan warna-warna dan menentukan kemerahan (redness), kehijauan (greenness) dari cahaya. Saturation menyatakan tingkat kemurnian suatu warna dan Value menyatakan banyaknya cahaya yang diterima mata tanpa memperdulikan warna. Ruang warna 
HSV dapat digunakan dengan baik dalam menunjang sistem temu kembali citra. Hasil penelitian menunjukkan bahwa penggunaan fitur warna dari ruang warna HSV lebih baik dari fitur warna RGB (Niranjanan \& Gopalan 2012). (Wicaksono et al. 2013) melakukan kombinasi fitur dalam sistem temu kembali citra Batik. Hasil penelitian menunjukkan kombinasi fitur cenderung menghasilkan akurasi yang lebih baik. Kombinasi transformasi curvelet dan ruang warna HSV dapat digunakan dengan baik dalam menunjang sistem temu kembali Batik. Kombinasi transformasi curvelet dan ruang warna HSV mendapatkan hasil terbaik dengan precision $96,85 \%$.

Pada kasus temu kembali citra kain tradisonal Batik dan Songket, pemilihan metode ekstraksi ciri yang tepat sangat dibutuhkan agar dapat mencapai perfomance yang baik pada sistem. Selain itu, metode ekstraksi ciri yang invariant terhadap perubahan rotasi juga sangat dibutuhkan.

Pada penelitian ini diusulkan sistem temu kembali citra kain tradisional dengan mengkombinasikan fitur tekstur dengan Local Binary Pattern (LBP) yang invariant terhadap rotasi dengan fitur warna dari ruang warna Hue, Saturation and Value (HSV). Dengan adanya kombinasi dua fitur tersebut, diharapkan dapat memberikan hasil perfomance yang lebih baik apabila dibandingkan dengan perfomance yang hanya menggunakan metode ekstraksi ciri tekstur saja atau fitur warna saja.

\section{Kajian Pustaka}

\subsection{LBP yang Invariant terhadap Rotasi}

LBP yang invariant terhadap rotasi (LBPROT) mengekstraksi ciri tekstur seperti yang ditunjukkan pada Gambar 1 . Nilai biner yang diperoleh dari hasil ekstraksi ciri tekstur LBP sebelum diubah ke nilai desimal, digeser hingga diperoleh nilai biner yang paling kecil. LBPROT dapat ditulis dengan persamaan (1).

$\operatorname{LBPROT}_{P, R}=L B P_{P, R}^{r i}=\min \left\{\operatorname{ROR}\left(\operatorname{LBP}_{P . R}, p\right)\right\}$

Selain itu, dapat juga menggunakan sistem pengindeksan. Misal, $\mathrm{P}$ sama dengan 8 maka LBPROT memiliki 36 pola dasar seperti yang ditunjukkan pada Gambar 2.

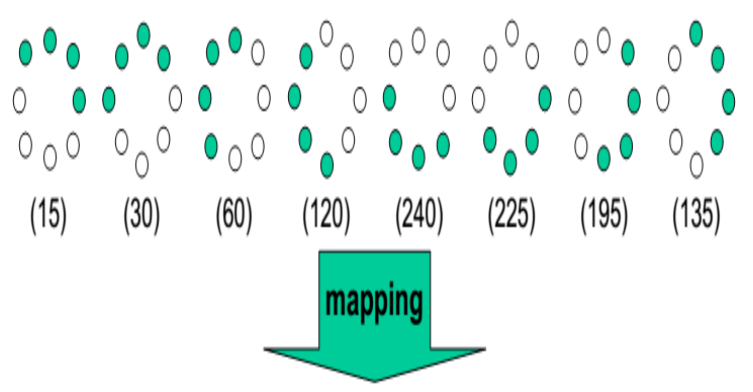

(15)

\section{Gambar 1. Penggeseran nilai biner untuk mencari kombinasi nilai terkecil}

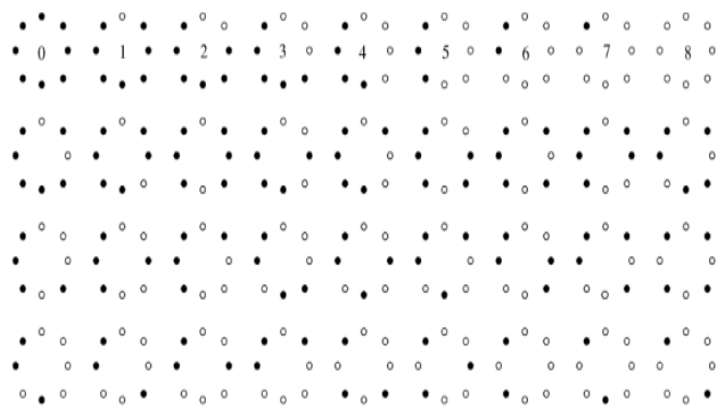

\section{Gambar 2. Ilustrasi 36 pola dasar} LBPROT

Sehingga, dapat dilakukan pengindekasaan seperti Gambar 3. Nilai biner yang diperoleh dari hasil ekstraksi ciri tekstur LBP sebelum diubah ke nilai desimal, digeser hingga polanya cocok dengan salah satu pola dari 36 indeks tersebut. Nilai indeks tersebut yang akan menjadi nilai fitur LBPROT. 


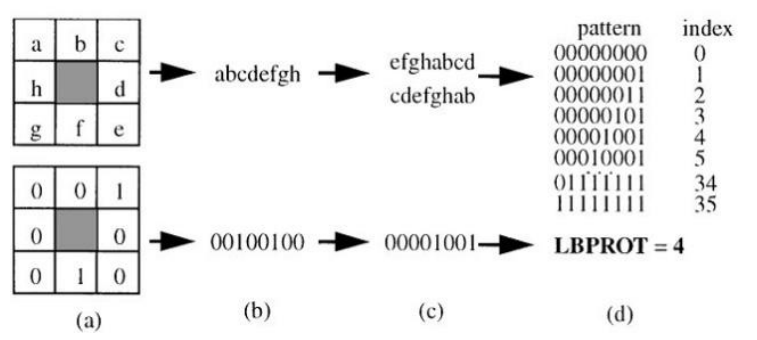

\section{Gambar 3. Proses LBPROT dengan cara pengindeksan.}

\subsection{LBP Multiresolusi yang Invariant}

Terhadap Rotasi

Pola-pola LBP tertentu memiliki karakteristik utama dari suatu tekstur. Pola-pola yang memiliki informasi penting ini dinamakan "uniform patterns". LBP dikatakan uniform jika struktur melingkar pola-pola binernya paling banyak terdiri atas dua transisi bit dari 0 ke 1 atau sebaliknya. Uniform patterns berfungsi untuk mengidentifikasi noda (spot), flat area atau dark spot, sudut, dan tepi. Hampir 90 persen dari tekstur merupakan uniform patterns (Ojala. 2002).

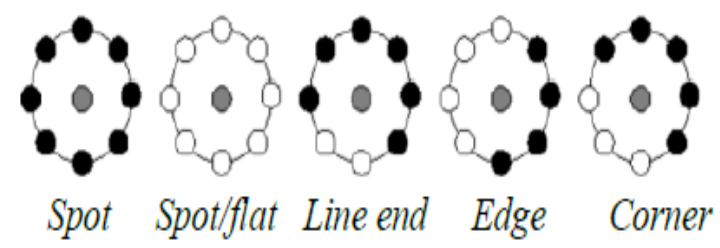

\section{Gambar 4. Tekstur uniform patterns.}

Penggabungan antara uniform patterns dengan rotation invariant dilambangkan $L B P_{P, R}^{r i u 2}$. Notasi ri menunjukkan rotation invariant dan $u 2$ untuk uniform patterns pada sampling points $\mathrm{P}$ dan radius $\mathrm{R}$. $L B P_{P, R}^{\text {riu2 }} \quad$ merupakan ukuran ketidaksensitifan (invariant) terhadap perubahan grayscale dan merupakan ukuran yang digunakan untuk pola spasial. Jumlah pola yang dihasilkan uniform patterns adalah $P \quad P-1+2$ bins. Ketika uniform patterns dirotasi sampai ke nilai minimum yang dimilikinya, jumlah pola yang dihasilkan menjadi $P+1$ bins. Rotation invariant uniform patterns diformulasikan sebagai berikut:

$$
L B P_{P, R}^{r i u 2}=\left\{\begin{array}{cr}
\sum_{p=0}^{p-1} s\left(g_{p}-g_{c}\right) & \text { If } U\left(L B P_{P . R}\right) \leq 2 \\
P+1 & \text { otherwise }
\end{array}\right.
$$

Jika pola yang diidentifikasi termasuk uniform patterns, akan dihitung banyaknya bit satu pada pola tersebut yang menentukan letak bin uniform patterns berada. Jika P, banyaknya sampling points sama dengan delapan, nilai $L B P_{P, R}^{r i u 2}$ adalah nol sampai dengan sembilan. Jika bukan uniform patterns akan masuk ke dalam bin terakhir, yaitu bin kesepuluh yang merupakan single bin non uniform patterns. Berdasarkan analisis statistik pada skala besar dataset gambar (Ojala. 2002), Sembilan pola uniform $L B P_{8,1}^{\text {riu2 }}$ berkontribusi rata-rata hampir $90 \%$ dari total data pola.

\subsection{Ruang Warna HSV}

Warna RBG (Red, Green, Blue), CMY (Cyan, Magenta, Yellow), dan YIQ adalah warna yang berorientasi pada perangkat keras. Sedangkan, warna HSV (Hue, Saturation, Value) berorientasi pada pengguna, yang berbasis daya tarik intuitif dari tint, shade, dan tone milik seniman. Sebagian besar pengolahan citra memperlakukan citra sebagai kumpulan piksel yang terdiri dari nilai warna merah, hijau, dan biru.

HSV (Hue, Saturation, Value) merupakan salah satu jenis ruang warna perseptual. Kompone hue direpresentasikan oleh sudut tiap warna pada bagian lingkaran kerucut. Komponen saturation direpresentasikan sebagai jarak dari pusat lingkaran. Warna dengan saturation tinggi terletak pada tepi terluar kerucut, sedangkan warna abu-abu (tidak memiliki saturation) terletak di pusat. Komponen brightness yang paling tinggi. Banyak penelitian yang melakukan 
proses kuantisasi warna dengan membagi kedalam sejumlah bins yang berbeda-beda. Pembagian bins dilakukan pada masingmasing kanal warna. Jumlah bins mempengaruhi perfoma dan beban komputasi, semakin besar jumlah bins semakin baik perfoma dan semakin besar beban komputasi, begitu pula sebaliknya.

Salah satu kombinasi bins yang baik dari segi perfoma serta beban komputasi yang ringan dan sering digunakan yaitu 72 bins (8 bins komponen $\mathrm{H}, 3$ bins komponen $\mathrm{S}$, dan 3 bins komponen V) (Niranjanan \& Gopalan 2012). Pembagian rentang pada bins tersebut didefinisikan pada persamaan (3).

$$
H=\left\{\begin{array}{c}
\text { Oifh } \in[316,20] \\
\text { 1ifh } \in[21,40] \\
\text { 2ifh } \in[41,75] \\
\text { 3ifh } \in[76,155] \\
4 i f h \in[156,190] \\
\text { 5ifh } \in[191,270] \\
6 i f h \in[271,295] \\
7 i f h \in[296,315]
\end{array} \quad V=\left\{\begin{array}{c}
\text { Difs } \in[0,0.2] \\
\text { lifs } \in[0.2,0.7] \\
\text { 2ifs } \in[0.7,1]
\end{array}\right\}\right.
$$

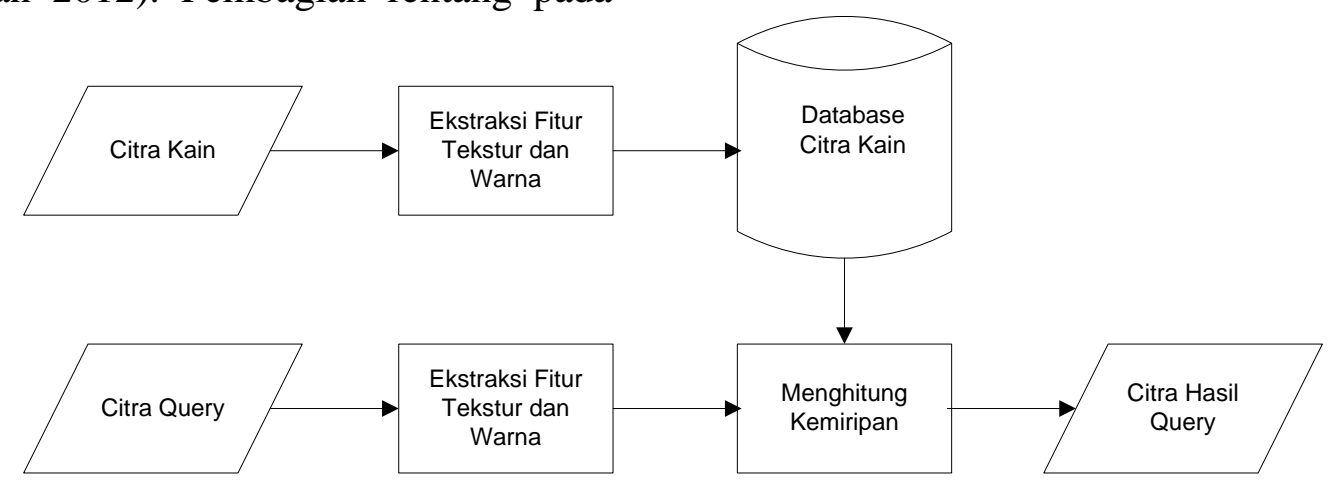

Gambar 5. Gambaran Umum Penelitian

Persamaan (3) menunjukkan pembagian rentang bins disetiap komponen warna, untuk komponen $H$ dimulai dari $316^{\circ}$ hingga $315^{\circ}$. Pembagian interval disetiap pada komponen ini tidak selalu sama, begitu pula dengan komponen $\mathrm{S}$ dan $\mathrm{V}$ yang dimulai dari 0 hingga 1 .

Sebuah eksperimen dengan pengaturan diatas menunjukkan bahwa tidak ada kehilangan informasi karena pengurangan dimensi. Dengan cara ini, tiga komponen vektor HSV bentuk vektor satu dimensi yang dikuantisasi ruang warna keseluruhan untuk 72 jenis warna utama. Jadi kita bisa menangani 72 bins dari histogram satu dimensi. Pembentukan vektor satu dimensi yang menghasilkan 72 bins warna ini menggunakan persamaan (4).

$$
G=9 H+3 S+V
$$

Hitungan ini dapat efektif dengan mengurangi waktu komputasi dan kompleksitas. Histogram warna diperoleh dengan mengkuantisasi warna dalam gambar ke 72 bins diruang warna HSV, dan menghitung jumlah piksel gambar dalam setiap bins.

\section{Metode Penelitian}

\subsection{Gambaran Umum}

Pada gambaran umum penelitian ini yang digambarkan pada Gambar 5, dimulai dengan citra asli kain tradisional melalui tahapan ekstraksi fitur tekstur menggunakan Local Binary Pattern (LBP) yang invariant terhadap rotasi untuk 
mendapat fitur tekstur dan ekstraksi fitur warna menggunakan ruang warna HSVdari citra kain tradisional untuk mendapatkan fitur warna.

Fitur yang diperoleh dari hasil ekstraksi kemudian dibandingkan dengan fitur semua objek yang terdapat di dalam database, melalui perhitungan similaritas dengan jarak. Hasil jarak ini sering disebut sebagai skor atau ranking. Seluruh skor diurutkan dari yang paling bernilai kecil ke yang paling besar. Objek-objek yang menghasilkan skor rendah adalah citra yang mirip dengan citra query. Untuk membatasi, hanya $n$ citra yang disajikan sebagai hasil query. Pada penelitian temu kembali citra kain tradisional ini, citra yang disajikan sebagai hasil temu kembali yaitu sebanyak 6 citra.

\subsection{Ekstraksi Fitur Tekstur}

Proses ekstraksi fitur pada penelitian ini menggunakan descriptor $L B P_{P, R}^{r i u 2}$. Proses awal ekstraksi citra ialah mengubah citra RGB menjadi citra grayscale seperti terlihat pada Gambar 6.

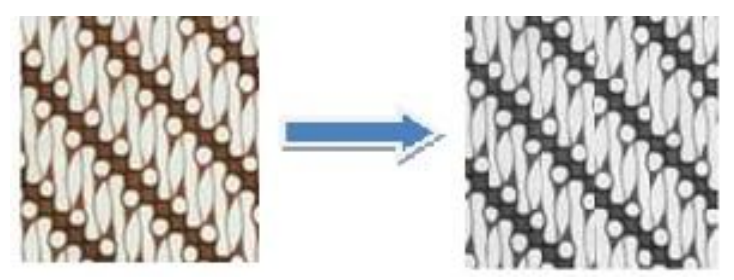

Gambar 6. Perubahan mode warna citra

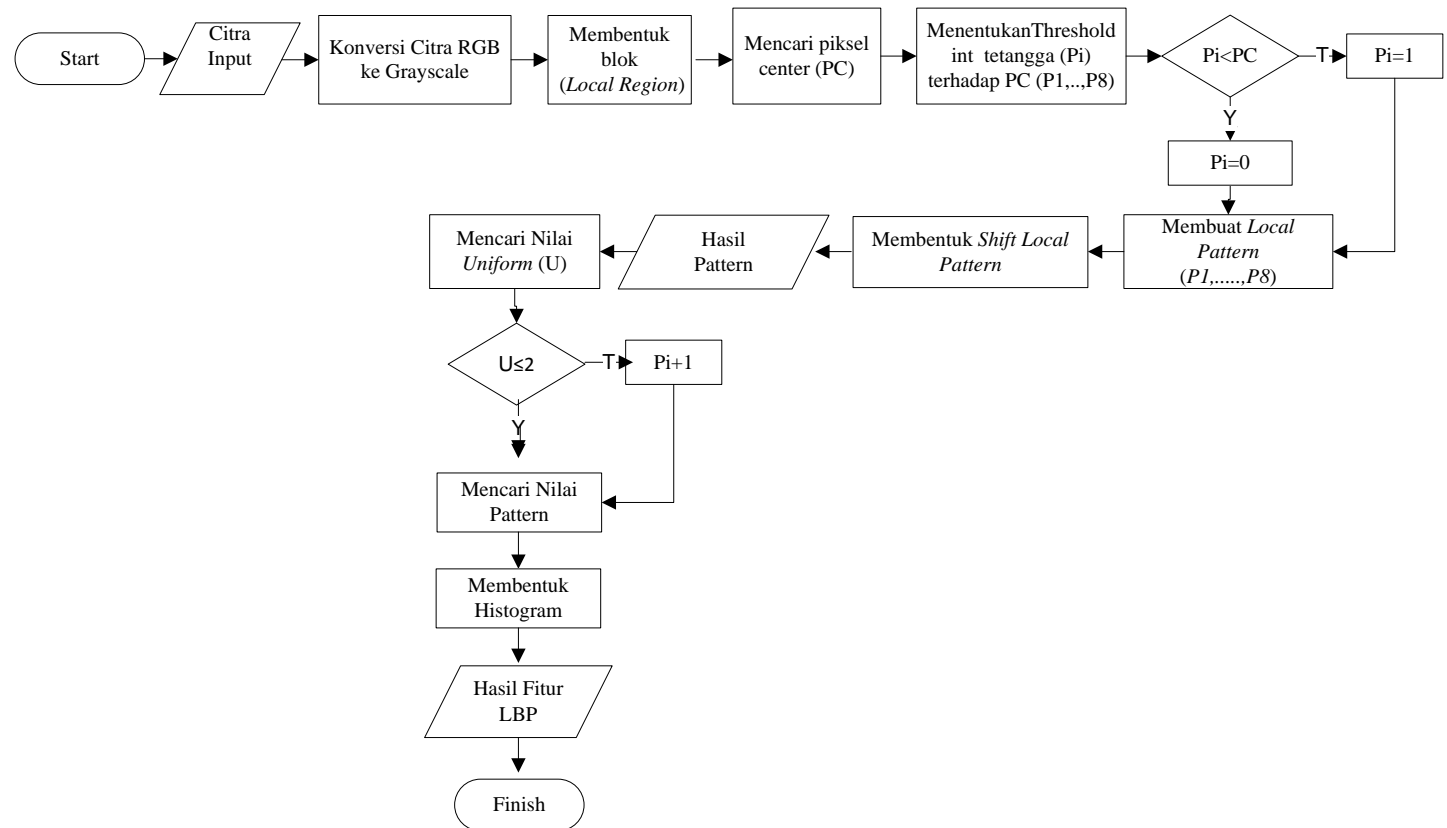

Gambar 7. Ekstraksi Ciri Tektur

Pengolahan selanjutnya membagi citra ke dalam beberapa blok (local region) sesuai dengan descriptor dan operator circular neighborhood (sampling points dan radius) yang digunakan. Penelitian ini menggunakan descriptor dan operator
$L B P_{P, R}^{r i u 2}$ dengan kuantisasi sudut 15 derajat. Penentuan ukuran blok dan kuantisasi sudut yang digunakan untuk satu local region menggunakan formula berikut : 
Blok $=($ Radius $\times 2)+1$

Kuantisasi Sudut $=\frac{2 \pi}{P}$

Ilustrasi pembagian citra ke dalam beberapa blok ditunjukkan pada Gambar 8 .
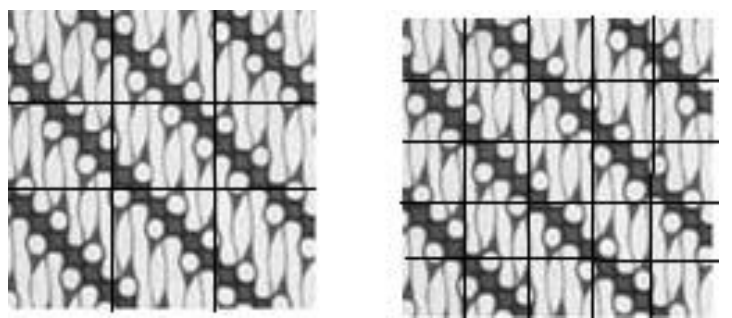

Gambar 8. Ilustrasi pembagian ukuran blok.

Ekstraksi tekstur dilakukan pada setiap blok. Setiap blok overlapping dengan blok berikutnya dengan jarak satu piksel. Masing-masing blok diekstraksi menggunakan Local Binary Pattern descriptor, yaitu : $L B P_{P, R}^{r i u 2}$.

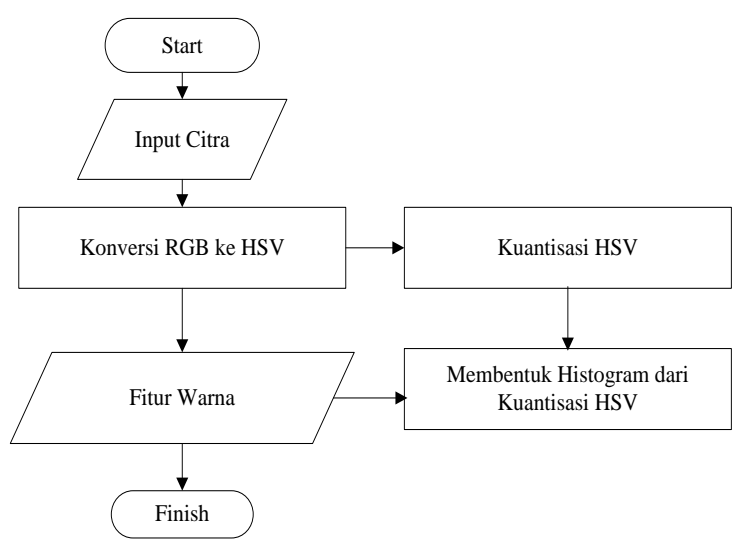

Gambar 10. Ekstraks Fitur HSV

Ilustrasi pembentukan histogram ditunjukkan pada Gambar 9. Histogram $L B P_{P, R}^{r i u 2}$ descriptor memiliki $\mathrm{P}+2$ bin dengan $\mathrm{P}$ merupakan banyaknya sampling points yang digunakan. Bin pertama sampai dengan $\mathrm{P}+1$ merupakan bin uniform patterns, sedangkan bin terakhir $(\mathrm{P}+2)$ merupakan single bin untuk non uniform patterns. Uniform LBP banyak
Ekstraksi tekstur menggunakan $L B P_{P, R}^{\text {riu } 2}$ descriptor mengolah setiap blok (local region) pada suatu citra menggunakan persamaan (2). Hasil dari pengolahan setiap blok menghasilkan pola LBP. Kemudian pola LBP setiap blok diidentifikasi masuk ke dalam uniform patterns atau nonuniform patterns. Jika termasuk uniform patterns, dihitung banyaknya bit satu yang ada pada pola tersebut yang akan menentukan letak bin uniform patterns tersebut berada.

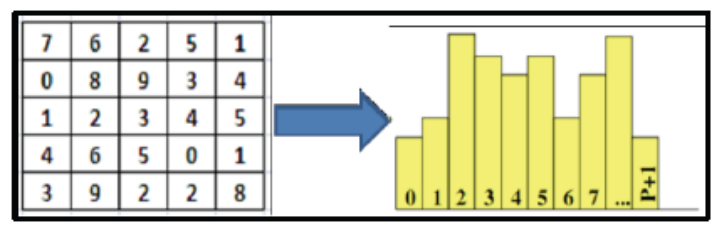

Gambar 9. Pembentukan histogram.

Hasil dari pengolahan setiap blok direpresentasikan melalui histogram yang merupakan frekuensi nilai $L B P_{P, R}^{\text {riu } 2}$ seluruh blok pada suatu citra.

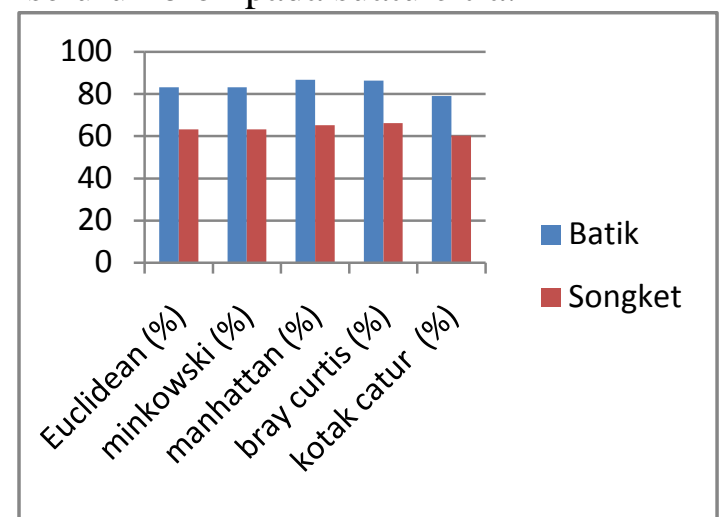

Gambar 11. Grafik perbandingan hasil recall fitur LBP

digunakan untuk melakukan lossy encoding sehingga dapat mengeliminasi data yang tidak relevan dan mengambil informasi yang berguna dengan menggunakan 10 nilai yang mungkin diambil. Ketika menggunakan pola uniform semua pola non-uniform akan disimpan ke satu histogram baru. Ini membuat panjang dari feature vector jauh 
lebih pendek dan membuat kita mampu untuk mendefinisikan versi simple dari LBP. Ekstraksi tekstur menggunakan $L B P_{P, R}^{r i u 2}$ diolah menggunakan operator $(8,1)$.

\subsection{Ekstraksi Fitur Warna}

Ruang Warna HSV digunakan untuk mendapatkan fitur warna dari citra kain. Tahapan untuk mendapatkan fitur warna ditunjukkan pada Gambar 10.

Pada tahap ekstraksi fitur menggunakan ruang warna $\mathrm{HSV}$, dilakukan perubahan ruang warna citra RGB menjadi HSV. Setelah itu dilakukan kuantisasi untuk mereduksi dimensi untuk optimasi perhitungan. Dari tiga kanal yakni $\mathrm{H}, \mathrm{S}$, dan $\mathrm{V}$ digabung menjadi satu nilai yang mempunyai rentang 0 sampai 71 . Dari 72 nilai ini dilakukan pembuatan histogram untuk mendapatkan jumlah piksel yang mempunyai nilai sesuai rentang tersebut. Didapatkan 72 vektor fitur dari histogram hasil kuantisasi HSV. Diagram alir untuk ekstraksi fitur ruang warna HSV ditunjukkan pada Gambar 10.

\section{Hasil Uji Coba}

Hasil ujicoba akan dijelaskan pada subbab 4.1 hasil uji fitur LBP, subbab 4.2 hasil uji coba fitur HSV, dan subbab 4.3 hasil uji kombinasi fitur.

\subsection{Hasil Uji Coba Fitur LBP}

Uji coba temu kembali dilakukan pada dataset citra Batik dan Songket menggunakan fitur tekstur LBP yang invariant terhadap rotasi. Untuk melihat perbandingan hasil rata-rata recall uji coba, pada uji coba ini digunakan jarak euclidean, jarak minkowski, jarak manhattan, jarak bray curtis, dan jarak kotak catur.
Pada dataset Batik penggunaan jarak manhattan memiliki perfomance terbaik dengan rata-rata recall $86,7 \%$, sedangkan untuk perfomance terendah dihasilkan dengan penggunaan jarak kotak catur dengan nilai rata-rata recall sebesar $79 \%$.

Pada dataset Songket penggunaan jarak bray curtis memiliki perfomance terbaik dengan rata-rata recall $66,3 \%$, sedangkan untuk perfomance terendah dihasilkan dengan penggunaan jarak kotak catur dengan nilai rata-rata recall sebesar $60,3 \%$.

\subsection{Hasil Uji Fitur Warna HSV}

Uji coba temu kembali dilakukan pada dataset citra Batik dan Songket menggunakan fitur warna HSV. Untuk melihat perbandingan hasil rata-rata recall uji coba, pada uji coba ini digunakan jarak euclidean, jarak minkowski, jarak manhattan, jarak bray curtis, dan jarak kotak catur.

Pada dataset Batik Penggunaan jarak manhattan dan bray curtis memiliki perfomance terbaik dengan rata-rata recall $98,7 \%$, sedangkan untuk perfomance terendah dihasilkan dengan penggunaan jarak euclidean dan minkowski dengan nilai rata-rata recall sebesar $97,7 \%$.

Pada dataset Songket penggunaan jarak kotak catur memiliki perfomance terbaik dengan rata-rata recall $96 \%$, sedangkan untuk perfomance terendah dihasilkan dengan penggunaan jarak euclidean dan minkowski dengan nilai rata rata recall sebesar $95 \%$. 


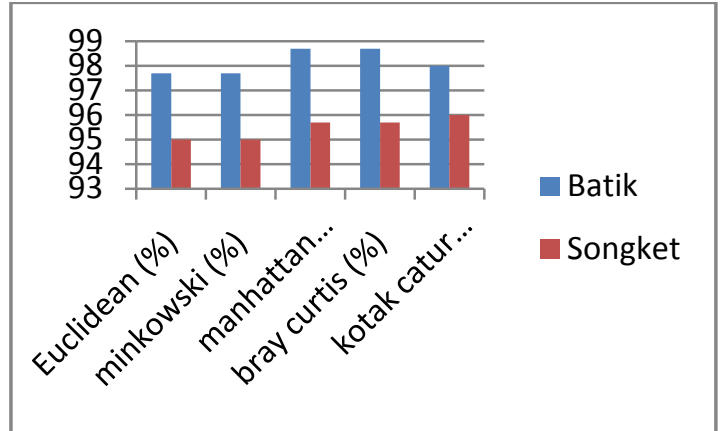

Gambar 12. Grafik perbandingan hasil recall fitur HSV

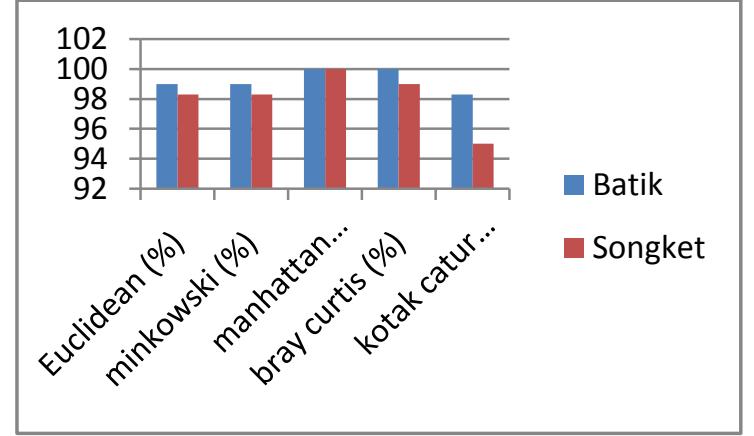

Gambar 13. Grafik perbandingan hasil recall kombinasi fitur

Tabel 1. Rata-rata hasil recall fitur LBP pada citra Batik dan Songket

\begin{tabular}{lccccc}
\hline Citra & $\begin{array}{c}\text { Euclidean } \\
(\boldsymbol{\%})\end{array}$ & $\begin{array}{c}\text { minkowski } \\
(\boldsymbol{\%})\end{array}$ & $\begin{array}{c}\text { manhattan } \\
(\boldsymbol{\%})\end{array}$ & $\begin{array}{c}\text { bray curtis } \\
(\boldsymbol{\%})\end{array}$ & $\begin{array}{c}\text { kotak catur } \\
(\boldsymbol{\%})\end{array}$ \\
\hline Batik & 83,3 & 83,3 & 86,7 & 86,3 & 79 \\
\hline Songket & 63,3 & 63,3 & 65,3 & 66,3 & 60,3 \\
\hline
\end{tabular}

Tabel 2. Rata-rata hasil recall fitur HSV pada citra Batik dan Songket

\begin{tabular}{|c|c|c|c|c|c|c|}
\hline Citra & $\begin{array}{l}\text { Euclidean } \\
(\%)\end{array}$ & $\begin{array}{l}\text { minkowski } \\
(\%)\end{array}$ & $\begin{array}{l}\text { manhattan } \\
(\%)\end{array}$ & $\begin{array}{l}\text { bray } \\
(\%)\end{array}$ & curtis & $\begin{array}{l}\text { kotak catur } \\
(\%)\end{array}$ \\
\hline Batik & 97,7 & 97,7 & 98,7 & 98,7 & & 98 \\
\hline Songket & 95 & 95 & 95,7 & 95,7 & & 96 \\
\hline
\end{tabular}

Tabel 3. Rata-rata hasil recall kombinasi fitur pada citra Batik dan Songket

\begin{tabular}{llllll}
\hline Citra & $\begin{array}{c}\text { Euclidean } \\
(\boldsymbol{\%})\end{array}$ & $\begin{array}{c}\text { minkowski } \\
(\boldsymbol{\%})\end{array}$ & $\begin{array}{c}\text { manhattan } \\
(\boldsymbol{\%})\end{array}$ & $\begin{array}{c}\text { bray curtis } \\
(\boldsymbol{\%})\end{array}$ & $\begin{array}{c}\text { kotak catur } \\
(\boldsymbol{\%})\end{array}$ \\
\hline Batik & 99 & 99 & 100 & 100 & 98,3 \\
Songket & 98,3 & 98,3 & 100 & 99 & 95 \\
\hline
\end{tabular}




\subsection{Hasil Uji Kombinasi Fitur}

Uji coba temu kembali dilakukan pada dataset citra Batik dan Songket menggunakan kombinasi fitur LBP dan fitur warna HSV. Untuk melihat perbandingan hasil rata-rata recall uji coba, pada uji coba ini digunakan jarak euclidean, jarak minkowski, jarak manhattan, jarak bray curtis, dan jarak kotak catur.

Pada dataset Batik penggunaan jarak manhattan dan bray curtis memiliki perfomance terbaik dengan rata-rata recall $100 \%$, sedangkan untuk perfomance terendah dihasilkan dengan penggunaan jarak kotak catur dengan nilai rata-rata recall sebesar $98,3 \%$.

Pada dataset Songket Penggunaan jarak manhattan memiliki perfomance terbaik dengan rata-rata recall $100 \%$, sedangkan untuk perfomance terendah dihasilkan dengan penggunaan jarak kotak catur dengan nilai rata-rata recall sebesar $95 \%$.

\section{Kesimpulan}

Keberhasilan dari temu kembali citra kain tradisional ini sangat bergantung pada keberhasilan metode ekstraksi fitur dalam merepresentasikan sebuah citra. Pemakaian kombinasi fitur tekstur LBP dan warna HSV memiliki perfomance yang lebih baik dibandingkan dengan hanya menggunakan fitur tekstur saja atau warna saja.

\section{Daftar Pustaka}

[1] Doost, H.E. \& Amirani, M. (2013), "Texture Classification with Local Binary Pattern Based on Continues Wavelet Transformation", International Journal of Advanced
Research in Electrical, Electronics and Instrumentation Engineering, 2(10), pp.4651-4656.

[2] Gao. Y, Zhang.H, and Guo.J. (2011), "Multiple Features Based Image Retrieval ", Proceedings of IEEE ICBNMT, pp.240-244.

[3] Kurniawardhani, A., Suciati, N. \& Arieshanti, I. (2014), "Klasifikasi citra batik menggunakan metode ekstraksi ciri yang invariant terhadap rotasi", JUTI, vol. 2, no. 2, pp.48-60.

[4] Malik, A, Effendy, T, Junus, A, dan Thaher, A. (2004), "Corak dan Ragi Tenun Melayu Riau", AdiCita, Yogyakarta.

[5] Niranjanan, S. \& Gopalan, S.P.R. (2012), "Performance Efficiency of Quantization using HSV Colour Space and Intersection Distance in CBIR", International Journal of Computer Application, vol. 42, pp.48-55.

[6] Ojala, T., Pietikäinen, M. \& Harwood, D. (1996), A comparative study of texture measures with classification based on featured distributions, Pattern, Recognition, vol.29, no. 1, pp.51-59.

[7] Ojala, T., Pietikäinen, M., \& Mäenpää, T. (2002). "Multiresolution Gray-Scale and Rotation Invariant Texture Classification with Local Binary Patterns," IEEE TPAMI, vol. 24, pp. 971-987.

[8] Pietikäinen, M., Ojala, T., \& Xu, Z. (2000), "Rotation-Invariant Texture Classification Using Feature Distributions," Pattern Recognition, vol. 33, pp.43-52.

[9] Wicaksono, A.Y., Suciati, N. \& Purwitasari, D. (2013), "Implementasi Transformasi Curvelet dan Ruang Warna HSV untuk Temu Kembali Citra Batik Berbasis Isi pada Situs Batik", Jurnal Teknik Pomits , vol 2, no.1, pp.1-3. 